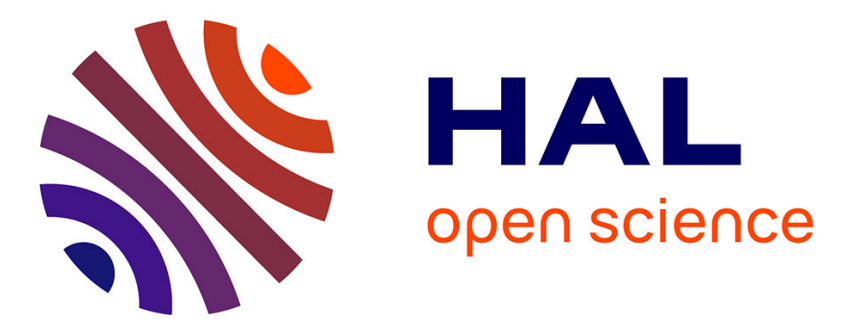

\title{
Biological properties of an OSB eco-product manufactured from a mixture of durable and nondurable species and natural resins
}

Nadine Amusant, Olivier Arnould, Antony Pizzi, Aurélien Depres, Reza Hammid Mansouris, Sandrine Bardet, Christine Baudassé

\section{To cite this version:}

Nadine Amusant, Olivier Arnould, Antony Pizzi, Aurélien Depres, Reza Hammid Mansouris, et al.. Biological properties of an OSB eco-product manufactured from a mixture of durable and nondurable species and natural resins. European Journal of Wood and Wood Products, 2009, 67, pp.439-447. 10.1007/s00107-009-0335-z . hal-00546295

\section{HAL Id: hal-00546295 \\ https://hal.science/hal-00546295}

Submitted on 12 Dec 2017

HAL is a multi-disciplinary open access archive for the deposit and dissemination of scientific research documents, whether they are published or not. The documents may come from teaching and research institutions in France or abroad, or from public or private research centers.
L'archive ouverte pluridisciplinaire HAL, est destinée au dépôt et à la diffusion de documents scientifiques de niveau recherche, publiés ou non, émanant des établissements d'enseignement et de recherche français ou étrangers, des laboratoires publics ou privés. 


\title{
Biological properties of an OSB eco-product manufactured from a mixture of durable and non durable species and natural resins
}

\author{
Nadine Amusant • Olivier Arnould • Antony Pizzi • Aurélien Depres • \\ Reza Hammid Mansouris · Sandrine Bardet · Christine Baudassé
}

\begin{abstract}
OSB panels were manufactured with a mixture of pine and cypress heartwood and lignin and tannin based resins in order to propose an eco-friendly wood composite. The resistance of OSB panels against Reticulitermes santonensis was tested according to EN 118 and EN 117 as well as in a field test. OSB made from cypress showed more resistance against the tested termite, the resistance decreased as the percentage of pine increased. The degree of attack differed according to the choice of standard procedure. The field test results revealed that in outdoor conditions and when the termites had a feeding choice, all mixtures showed the same behaviour. The decay resistance was assessed according to EN 12038, and the results revealed that the resistance increases when the percentage of cypress increases.
\end{abstract}

\section{Dauerhaftigkeit von OSB-Ökoplatten aus einer Mischung aus dauerhaften und nicht dauerhaften Holzarten und Naturharzen}

Zusammenfassung Aus einer Mischung aus Kiefern- und Zypressenkernholz sowie Harzen auf Lignin- und Tanninba-

N. Amusant $(\bowtie) \cdot C$. Baudassé

Laboratoire de Préservation, CIRAD,

73 rue JF Breton,

TA B 40-16, cedex 5, 34398 Montpellier, France

e-mail: nadine.amusant@cirad.fr

O. Arnould $\cdot$ S. Bardet

LMGC-CNRS UMR 5508 CC048, Université Montpellier 2,

48 Place Eugène Bataillon,

cedex 5, 34095 Montpellier, France

A. Pizzi - A. Depres $\cdot$ R. H. Mansouris

Lermab, ENSTIB,

27 rue Merle blanc,

BP 1041, cedex 9 Epinal, France sis wurden OSB-Platten als umweltfreundlicher Holzwerkstoff hergestellt. Die Resistenz dieser OSB-Platten gegen Reticulitermes santonensis wurde gemäß EN 118 und EN 117 sowie in einem Feldversuch untersucht. Aus Zypressenholz hergestellte OSB-Platten wiesen eine höhere Resistenz gegen diese Termitenart auf. Diese nahm mit zunehmendem Kiefernholzanteil ab. Dabei hing die Höhe des Befalls vom gewählten Prüfverfahren ab. Die Ergebnisse des Feldversuchs zeigten, dass sich alle Mischungen unter Freilandbedingungen bei gegebenem Termitenbefall gleich verhielten Die Resistenz wurde darüber hinaus gemäß EN 12038 bestimmt. Dabei zeigten die Ergebnisse, dass die Resistenz mit zunehmendem Anteil an Zypressenholz zunimmt.

\section{Introduction}

Wood composite production has increased dramatically over the past three decades due to a number of factors. The changing wood supply, the development of new composite technologies and the widespread acceptance by architects and builders have each contributed to increasing wood composite production (Gardner et al. 2003). OSB panels designed for end uses where decay or termite attack are potential hazards often contain fungicides or insecticides because these panels are generally manufactured from non durable wood species and therefore have little inherent biological resistance. Zinc borate has been added to OSB in a commercial level to improve the resistance. Leachability and toxicity are major problems that arise when preservative chemicals are used to treat composite products. Sometimes interactions between resins and preservatives are detrimental to bond performance and ultimately reduce the physical properties of the panel (Kirkpatrick and Barnes 2006). Moreover, it is widely known that wood-based composites are generally not resis- 
tant to termite attack (Muin and Tsunoda 2003). To reduce the widespread use of chemical preservatives to protect biobased materials against biodeterioration, efforts should be focused on using naturally durable species to enhance the long-term service of these materials in hazardous environments (Behr 1972, Yalinkilic et al. 1998, Evans et al. 2000, Kartal and Green 2003). There is increasing concern about the safety and environmental effects of many artificial chemicals used to preserve wood and a growing interest in alternative wood preservation methods. There is also renewed interest in using naturally durable species to overcome health risks and environmental problems associated with the application of chemical wood preservatives. It has been reported that mixing durable and nondurable species increases the fungal and termite resistance of composites (Kartal and Green 2003, Wan et al. 2007). A second environmental concern is the control of volatile and semi-volatile compounds derived from resins. Modern product development should thus consider both the ecological and technical properties of the products. Natural resins based on lignin (Lei et al. 2007, Mansouri et al. 2007) or tannin (Garnier et al. 2002, Ballerini et al. 2005) are potential options that could be used to obtain environment-friendly products that meet consumers' needs. This study was carried out to investigate the possibility of developing eco-products with durable and nondurable species and natural resin. An optimal combination that could give the best performance from a biological standpoint has been developed.

Table 1 Composition of OSB specimens

Tabelle 1 Zusammensetzung der OSB-Proben

\begin{tabular}{lc}
\hline Composition & Type of resin \\
\hline $100 \%$ pine & Tannin \\
$100 \%$ pine & Lignin \\
$100 \%$ pine & MUF/pMDI \\
$100 \%$ cypress & Tannin \\
$100 \%$ cypress & Lignin \\
$100 \%$ cypress & MUF/pMDI \\
$75 \%$ cypress $-25 \%$ pine & Tannin \\
$75 \%$ cypress $-25 \%$ pine & Lignin \\
$50 \%$ cypress $-50 \%$ pine & Tannin \\
$50 \%$ cypress $-50 \%$ pine & Lignin \\
\hline
\end{tabular}

\section{Experimental methods}

\subsection{Manufacturing OSB panels}

The OSB specimens were made from cypress (Cupressus sempervirens), pine (Pinus sylvestris) or a mixture of these woods, as shown in Table 1. The original trees were around 60 years old and were grown in the Grenouillet Arboretum (France), felled and crosscut into $1 \mathrm{~m}$ long logs. The log bark and sapwood of cypress were removed. Pine heartwood and sapwood logs were kept as they both are non durable against termites. Flakes $\left(100 \times 10 \times 6 \mathrm{~m}^{3}\right)$ were obtained from thin veneer. Care was taken at this and at subsequent stages to keep the strands from the different species separate. The flakes were then dried to about 6-7\% moisture content before gluing. Commercial MUF (melanin-urea-formaldehyde) and pMDI (polymethylenediphenyl-diisocyanate) resins were used as reference. Two natural resins were tested, i.e. tannin-based resin (tannin from pine with hexamine hardener) and lignin-based resin (lignin with paraformaldehyde and pMDI), to blend the flakes. The panel manufacturing conditions are presented in Table 2. The blender was a home made laboratory blender based on the model of Dakota peat blenders (Dakota Peat \& Equipment, Grand Forks, North Dakota, USA). Three panels were manufactured for each species-resin combination. All panels were conditioned in a climatic room at $20^{\circ} \mathrm{C}$ and $65 \%$ relative humidity $(\mathrm{RH})$ for 2 months prior to biological tests.

\subsection{Test specimens and sampling}

A total of 30 OSB panels $\left(350 \times 350 \times 14 \mathrm{~mm}^{3}\right)$ were prepared corresponding to three panels for each resin-species combination. For each panel, 18 OSB test specimens of $50 \times 50 \times 14 \mathrm{~mm}^{3}$ were cut and maintained for eight weeks in a climatic room $\left(65 \% \mathrm{RH}\right.$ and $\left.20^{\circ} \mathrm{C}\right)$ until constant mass. All OSB specimens were weighed prior to the bioassays. Cypress heartwood was used for the solid wood controls. The calculation of the mass of durable and non durable species was carried out in order to obtain a density around
Table 2 Panel manufacturing parameters

Tabelle 2 Herstellungsparameter der Platten

Panel dimension
Panel construction
Mass distribution
Wood species
Target mat moisture content
Resin content
Blender
Blender rotation speed
Pressing cycle
Press temperature
Total press time
Replicate

Replicate
$350 \mathrm{~mm} \times 350 \mathrm{~mm} \times 14 \mathrm{~mm}$

Three layers -2 exterior layers perpendicular to the middle one 20\%: $60 \%: 20 \%$ side/core/side

Pine, cypress $7 \%-6 \%$

$13 \%$ side and $11 \%$ core

Dakota type

$900 \mathrm{rpm}$

90 s 35 bar, 120 s 16 bar, 150 s 8 bar

$175^{\circ} \mathrm{C}$ (plate surface)

$6 \mathrm{~min}$

3 
$600 \mathrm{~kg} / \mathrm{m}^{2}$; according to the density of pine and the cypress and the dimension of the panel. All the OSB panels were in the density range of $660 \pm 10 \mathrm{~kg} / \mathrm{m}^{3}$.

\subsection{Termite bioassay according to EN 118}

The OSB specimens and the solid wood were assessed for termite resistance according to the EN 118 procedure (AFNOR 2005b). With this method, termites are only in contact with one side of the OSB specimen. Reticulitermes santonensis termites were collected on Oleron Island (France) and transported to the laboratory where the termites were bred. Termites remained in breeding tubs from the collection date in May 2005 until their extraction in February 2006. The ground glass end of one glass tube (110 mm length $-25 \mathrm{~mm}$ width) was attached with resin at the centre of the OSB test specimens. Some wet sand $(1: 4$ $\mathrm{v} / \mathrm{v}$ water-sand ratio) was added to each tube, taking up at least two-third of the volume of the tube, and 250 termite workers, 5 soldiers and 5 nymphs were distributed.

Test assemblies were kept in a testing chamber $\left(27^{\circ} \mathrm{C}-\right.$ $70 \% \mathrm{RH}$ ) for eight weeks. A total of nine replicates for each tested panel type (resin-species combination) and six cypress wood blocks were assessed. Three pine (Pinus sylvestris) sapwood samples $\left(50 \times 50 \times 10 \mathrm{~mm}^{3}\right)$ were used to check the termite virulence. At the end of the test period, the tubs were unsealed and the number of live termite workers, soldiers and nymphs were counted in order to determine the worker survival rate. In addition, each OSB specimen was examined and visually rated using a standard rating system (AFNOR 2005b; Table 3). The cleaned OSB specimens were conditioned in a climatic room $\left(20^{\circ} \mathrm{C}\right.$ and $\left.65 \% \mathrm{RH}\right)$ until constant mass and then reweighed to determine the weight loss according to the initial mass prior to the bioassay. The bioassay was valid if the three virulence control specimens corresponded to level 4 when visually examined and if the colonies had a survival rate of at least $50 \%$.

\subsection{Termite bioassay according to EN 117}

The OSB specimens and solid wood were also assessed for termite resistance using the EN 117 procedure (AFNOR

Table 3 Visual ratings in the termite test (see AFNOR 2005a,b for more details)

Tabelle 3 Klassifizierung des Termitenbefalls durch optische Bewertung (nähere Angaben siehe AFNOR 2005a,b)

\begin{tabular}{lc}
\hline Rating & Severity of termite attack \\
\hline 0 & No attack \\
1 & Attempted attack \\
2 & Slight attack \\
3 & Average attack \\
4 & Strong attack \\
\hline
\end{tabular}

2005a). With this method, termites can be in contact with all sides of the OSB specimens. In a separate tub containing an adequate quantity of remoistened sand, a glass ring was placed in the middle of its vertical walls of the test container along with a group of termites (250 workers, 5 soldiers and 5 nymphs). The containers were placed in a climatic room $\left(27^{\circ} \mathrm{C}-70 \% \mathrm{RH}\right)$ for $48 \mathrm{~h}$ in order to ensure that the termites had settled in properly. Then the OSB specimens and solid wood were carefully placed on the glass ring. One of the narrow longitudinal sides was resting on the ring with a wide longitudinal side in contact with one of the test container walls. Test assemblies were kept in the testing chamber $\left(27^{\circ} \mathrm{C}\right.$ $-70 \% \mathrm{RH})$ for eight weeks. The sample size and evaluation methods were the same as those described above in Sect. 2.3.

\subsection{Termite field test}

The OSB specimens were directly exposed to tropical conditions (French Guiana). A non-durable wood species yayamadou (Virola surinamensis) was used too in order to attract termites and monitor their virulence. The specimens were placed under cover in order to protect them from bad weather and avoid fungal attack. The different OSB specimens were installed horizontally in a $1 \times 1 \mathrm{~m}^{2}$ area directly in contact with the yayamadou control wood blocks. The dimensions of the specimens were $70 \times 50 \times 14 \mathrm{~mm}^{3}$. A total of nine replicates for each combination (resinspecies combination) were used. The OSB specimens were randomly laid side by side. Each test specimen was sandwiched between two yayamadou wood blocks. A total of nine replicates from each tested panel type (resin-species combination) have been tested. At the end of the exposure period (six months), the OSB specimens and yayamadou solid wood blocks were cleaned, stabilised in a climatic room $\left(65 \% \mathrm{RH}\right.$ and $\left.20^{\circ} \mathrm{C}\right)$ in order to determine the mass loss. The OSB specimens were regularly examined to monitor the presence of termites. These assays were conducted at the Kourou research station in French Guiana $\left(5^{\circ} 09 \mathrm{~N}, 52^{\circ} 3 \mathrm{O}\right)$. This station has an equatorial climate with a mean annual rainfall of $3000 \mathrm{~mm}$ and a mean annual temperature of $26^{\circ} \mathrm{C}$. Nasitutermes existiosus, Heteroterme tenuis and Coptotermes testaceus are the key target termite species. The trial began in January 2007 and lasted six months.

\subsection{Decay resistance test according to EN 12038}

OSB specimens $\left(50 \times 50 \times 14 \mathrm{~mm}^{3}\right)$ were subjected to a decay resistance test according to the EN 12038 standard method (AFNOR 2003). A total of nine replicates from each tested panel type (resin-species combination) and six solid 
sapwood blocks from pine (size control specimens) of the same dimension as the OSB specimens and six solid wood blocks from cypress heartwood $\left(50 \times 25 \times 15 \mathrm{~mm}^{3}\right)$ were exposed to each decay fungus (Coniophora puteana, Pleurotus ostreatus). The moisture balance was calculated in a series of wood samples from each panel type so as to determine the dry mass prior to exposure of the OSB specimens. After 16 weeks of incubation at $21^{\circ} \mathrm{C}$ and $70 \%$ $\mathrm{RH}$, surface fungus mycelium was removed, the specimens were dried and weight losses were determined as a percentage of the initial mass. Six sapwood pine blocks were used to monitor the fungus virulence. The test was considered valid if the virulence value was over $20 \%$ and the OSB panel was considered very resistant if the mean mass loss was less than $3 \%$. When the mean mass loss was over 3\%, the degradation susceptibility index (DSI) was calculated, i.e.

$\mathrm{DSI}=T \times 100 / S$

where $T$ is the percentage mass loss of an individual OSB specimen, and $S$ is the mean percentage mass loss of the appropriate set of size control specimens. The mean DSI values were calculated for the specimens of the test product exposed to each test fungus.

DSI $=100$ indicated that the panel had no resistance and low DSI values indicated that the panel was resistant to fungal attack.

\subsection{Statistical analysis}

A suitable analysis of variance (ANOVA) was performed, with mass losses and termite mortality rates as variables in order to assess the effects of the panel composition (percentage of pine) and resin type on the resistance to biodeterioration.

\section{Results}

\subsection{Results according to EN 118}

The mean mass losses, percentage termite survival and visual rate are shown in Table 4. The attack of pine sapwood clearly showed that termites were active under the test conditions, thus allowing comparison of the termicidal performances of the wood-based composites. According to EN 118,250 termites were exposed to a $3.14 \mathrm{~cm}^{2}$ panel surface. According to the visual rating, all panels were highly attacked but the mass loss results showed that the panel composition had a significant effect on the susceptibility of OSB specimens to termite attack. The resistance depended on the percentage of durable wood species in the panel and the choice of resin. Panels composed of $100 \%$ pine were more resistant than solid wood: the percentage of termite survival and mass loss were lower than in pine sapwood blocks. Termites attacked earlywood in pine sapwood faster than they did in composite panels because the portion of growth ring is softer and the resin in the panel may interfere. There was a significant effect $(p<0.0001)$ of the panel composition on mass losses in OSB specimens. Cypress solid wood is durable against termites (no attack after five weeks). Panels composed of $100 \%$ cypress wood showed shallow testing nibbles, which were mainly on the surface and the termites died after the attack. According to the standard (information from EN 118 not shown in Table 3) the samples undergoing erosions higher than $1 / 10$ of the area of the sample or having a hole bigger than $3 \mathrm{~mm}$ are considered as highly attacked. In our case the OSB samples showed nibbles on an area bigger than $1 / 10$ of the tested area. A deeper area was nibbled on $75 \%$ cypress panels. Termites built galleries within many panel specimens made with $50 \%$ cypress, while attacks were limited to the surface of specimens with higher cypress contents. The study of mass losses clearly showed that specimens containing high percentages of cy-

Table 4 Percentage mean mass losses in OSB specimens, survival workers, visual rating according to EN 118. () standard deviation Tabelle 4 Mittlerer prozentualer Masseverlust der OSB-Proben, überlebende Arbeiter, optische Bewertung gemäß EN 118. () Standardabweichung

\begin{tabular}{lcccc}
\hline OSB type & Resin & Average mass loss (\%) & Rating scale & Survival (\%) \\
\hline Control = sapwood solid pine & & $14.8(0.2)$ & 4 & $66.1(4.2)$ \\
Cypress solid wood & & 0.2 & 0 & 0 \\
$100 \%$ pine & Tannin & $7.6(2.1)$ & 4 & $59.1(21)$ \\
$100 \%$ pine & Lignin & $4.0(1.3)$ & 4 & $30.6(19)$ \\
$100 \%$ pine & MUF/pMDI & $1.8(1.8)$ & 4 & $11.2(22)$ \\
$50 \%$ cypress $-50 \%$ pine & Tannin & $6.2(0.6)$ & 4 & $54.7(28.5)$ \\
$50 \%$ cypress $-50 \%$ pine & Lignin & $1.7(0)$ & 4 & $36.5(22.1)$ \\
$75 \%$ cypress $-25 \%$ pine & Tannin & $5.3(2.2)$ & 4 & $13.0(16.0)$ \\
$75 \%$ cypress $-25 \%$ pine & Lignin & $1.0(0.7)$ & 4 & $16.5(16.0)$ \\
$100 \%$ cypress & Tannin & $1.0(0.3)$ & 4 & 0 \\
$100 \%$ cypress & Lignin & $0.8(0.8)$ & 4 & 0 \\
$100 \%$ cypress & MUF/pMDI & $0.5(0.2)$ & 4 & 0 \\
\hline
\end{tabular}


press heartwood were more resistant to termite attack than those containing a high percentage of pine. All differences between the different resin-species combinations were significant at the $1 \%$ level.

The percentage of termite survival relative to control is an important index of the panel specimen toxicity level. Survival data for controls demonstrated how termites were able to survive during the bioassays. There was evidence that specimens containing cypress were toxic to termites, i.e. the survival percentages decreased when the percentage of cypress increased, with no survival noted in the $100 \%$ cypress OSB specimens after five weeks exposure. With the cypress-pine mixture, termite mortality was higher than in the control. Volatiles from cypress suppressed termite activity: no termite survival on solid cypress wood and no attack after three weeks. The resistance of cypress heartwood to termite attack has been attributed to the presence of tropolones, particularly thujaplicine in the heartwood (Zavarin et al. 1959a,b, Haluk and Roussel 2000). Tropolones were found to have a strong potent insecticidal activity against $C$. formosanus (Morita et al. 2003), but other compounds like terpene fractions may also confer durability. This information explains why all the termites died in the solid cypress wood blocks. The better resistance observed for the solid block compared for the $100 \%$ cypress OSB specimens could be explained by a decrease of extractives activity. High temperatures and steam encountered in OSB fibreboard manufacturing conditions may cause a loss of some extractives responsible for termite resistance in the outer layers. Termites have to nibble the surface of the OSB specimen before dying because the extractives remain intact in deep area. The visual rating results disqualified all OSB specimens because the laboratory test conditions were more severe than exposure in service conditions.

Differences in mass losses after termite attack were minimal for panels with $100 \%$ pine and those with $50 \%$ cypress and pine. The consumption rates were directly related to the termite feeding activity, the presence of durable species clearly showed that the wood-based composites had different levels of resistance to termite attack. The highest termite resistance was obtained for the $100 \%$ cypress panels, followed by $75 \%$ cypress and $25 \%$ pine panels. Table 5 shows the results of an ANOVA to assess the effects of resin on mass loss in wood-based composites due to Reticulitermes santonensis. This analysis revealed that the effects of resin significantly affected the termicidal performance of OSB. Note that the OSB specimens made with tannin-based resin were consumed at a higher rate than the OSB specimens made with industrial or lignin-based resin (Table 4).

\subsection{Results according to EN 117}

The bioassay was carried out only with the best results obtained with the EN 118 standard. Lignin-based resin and pine-cypress mixtures (100, 25, and $0 \%$ of pine) were tested. The assessment results for the different mixtures were the same as those obtained for EN 118: $100 \%$ cypress panels were more resistant than $75 \%$ cypress and $100 \%$ pine panels (Table 6). The panel composition had a significant effect $(p<0.0001)$ on the mass loss in OSB specimens. In the presence of cypress, all termites died after five weeks of exposure. The percentage of mass loss was higher than that obtained for EN 118 with $100 \%$ pine. This was due to the fact that termites could attack all sides of the OSB specimens. With the EN 118 standard, termites were in contact with a small area of the OSB specimens. Because of this difference in the area exposed to termites, the degree of attack was less homogeneous than with EN 118, e.g. with $100 \%$ cypress, most of the OSB specimens (45\%) underwent level 1 of degree of attack while only $11 \%$ underwent level 4 of degree of attack (Table 7). Termites built galleries within many panel specimens with $100 \%$ pine, while the attack was limited to the surface of the panel specimens with higher cypress content. Specimens containing high percentages of

Table 5 Variance analysis - resin effect on termite resistance (mean mass loss)

Tabelle 5 Varianzanalyse - Einfluss des Harzes auf die Termitenresistenz (mittlerer Masseverlust)

\begin{tabular}{lccccc}
\hline OSB panels & Degrees freedom & Square root & Mean square & $F$ & $P$ \\
\hline Model & 2 & 185.0 & 92.5 & 17.44 & $<0.0001$ \\
Residue & 67 & 355.2 & 5.3 & & \\
Total & 69 & 540.2 & & & \\
\hline
\end{tabular}

Table 6 Percentage mean mass loss in OSB specimens, visual rating and survival workers according to EN 117. () = standard deviation Tabelle 6 Mittlerer prozentualer Masseverlust der OSB-Proben, optische Bewertung und überlebende Arbeiter gemäß EN 117. () Standardabweichung

\begin{tabular}{lccc}
\hline Panel type & Resin & Average mass loss $(\%)$ & Survival $(\%)$ \\
\hline Control = sapwood solid pine & - & $15(0.3)$ & $70(4.2)$ \\
$100 \%$ pine & Lignin & $6.4(1.5)$ & $60.1(20.7)$ \\
$75 \%$ cypress $-25 \%$ pine & Lignin & $1.1(0.3)$ & 0 \\
$100 \%$ cypress & Lignin & $0.4(0.3)$ & 0 \\
\hline
\end{tabular}


Table 7 Distribution of the OSB specimens according to the degree of attack by termites and the percentage of durable species - EN 117 Tabelle 7 Verteilung der OSB-Proben nach Höhe des Termitenbefalls und des Anteils an dauerhaftem Holz - gemäß EN 117

\begin{tabular}{|c|c|c|c|c|c|}
\hline Panel type & Attack 0 & Attack 1 & Attack 2 & Attack 3 & Attack 4 \\
\hline$\overline{\text { Control }}$ & 0 & 0 & 0 & 0 & 100 \\
\hline $100 \%$ pine & 0 & 0 & 0 & 0 & 100 \\
\hline $75 \%$ cypress $-25 \%$ pine & 0 & 0 & 56 & 44 & 0 \\
\hline $100 \%$ cypress & 0 & 45 & 22 & 22 & 11 \\
\hline
\end{tabular}

cypress heartwood were clearly more resistant to termite attack and validated the results obtained for EN 118.

\subsection{Field test results}

Although the target termite species present under the tropical area are different from the species used in the laboratory tests, termite resistance was tested under a tropical climate because termites are more virulent and the results could be obtained more rapidly in a choice situation. Termites were present throughout the bioassay period. The mass loss obtained with the control yayamadou wood ( $\mathrm{Vi}$ rola surinamensis) was $25 \%$, and the wood samples were completely degraded by the termite species (Table 8 ). The results obtained with the different mixtures of cypress confirmed the ones obtained under the controlled laboratory bioassay conditions. The presence of cypress prevented termite attack: termites nibbled on a small area. There was no significant difference when comparing panels with different proportions of cypress: all OSB specimens had the same performance. Indeed, in outdoor conditions, termites had feeding preferences and avoided contact with all OSB specimens containing cypress. These results confirmed that some wood components affect the feeding-preference activities of some termite species. Because of the random installation of the OSB specimens, the high variability in the results with $100 \%$ pine OSB panels could be explained by the interaction with OSB specimens containing cypress. OSB specimens made with lignin-based resin were more resistant than those made with tannin-based resin $(P<0.001)$.

\subsection{Decay resistance according to EN 12038}

Tables 9 and 10 show the mass losses obtained with $C o$ niophora puteana and Pleurotus ostreatus. The fungus virulence validated the assay results $(32.6 \%$ mass loss for $\mathrm{Co}$ niophora puteana and $23.4 \%$ for Pleurotus ostreatus). Cypress heartwood was very resistant, i.e. mass losses were under $1 \%$. After being subjected to decay fungi for 16 weeks, OSB specimens and control were completely colonized by the fungus. Less mycelia growth was noted on the $100 \%$ cypress panels. There was a significant effect of the panel composition on the susceptibility of OSB specimens against Coniophora puteana attack (Table 9). OSB specimens made with $100 \%$ cypress showed the same mass loss as the solid wood block and were more resistant than the OSB specimens mixed with pine. The resistance depended on the percentage of wood from durable species in the panel and the type of resin. As would be expected, weight loss increased as the proportion of pine in the mix-
Table8 Field test - percentage mean mass loss in OSB specimens according to different resins. () standard deviation Tabelle 8 Feldversuch: Prozentualer Masseverlust der OSB-Proben in Abhängigkeit von Harz. () Standardabweichung

Table9 Percentage mean mass loss in OSB specimens, and DSI according to EN 12038 Coniophora puteana. () standard deviation

Tabelle 9 Mittlerer prozentualer Masseverlust der OSB-Proben und Befallsanfälligkeitsindex (DSI) gemäß EN 12038 Coniophora puteana.

() Standardabweichung

\begin{tabular}{lccc}
\hline Panel type & Tannin & Lignin & MUF/pMDI \\
\hline $100 \%$ pine & $14.7(13.9)$ & $18.2(15.5)$ & $5.7(3.4)$ \\
$50 \%$ cypress $-50 \%$ pine & $1.3(0.4)$ & $0.7(0.2)$ & - \\
$75 \%$ cypress $-25 \%$ pine & $1.3(0.5)$ & $0.1(0.2)$ & - \\
$100 \%$ cypress & $1.2(0.3)$ & $0.3(0.2)$ & $0(0)$ \\
Yayamadou & & $25.0 \%$ & \\
\hline
\end{tabular}

\begin{tabular}{lccc}
\hline OSB type & Resin & Average mass loss (\%) & DSI (\%) \\
\hline Control & - & $32.6(7.1)$ & - \\
Cypress solid wood & - & 0.9 & - \\
$100 \%$ pine & Tannin & $45.5(5.9)$ & $116.9(15.2)$ \\
$100 \%$ pine & Lignin & $31.5(19.1)$ & $81.0(49.2)$ \\
$100 \%$ pine & MUF/pMDI & $21.9(14.3)$ & $56.2(36.9)$ \\
$50 \%$ cypress $-50 \%$ pine & Tannin & $25.7(4.8)$ & $66.2(12.4)$ \\
$50 \%$ cypress $-50 \%$ pine & Lignin & $16.9(2.4)$ & $43.4(6.3)$ \\
$75 \%$ cypress $-25 \%$ pine & Tannin & $8.8(4.3)$ & $22.7(11.0)$ \\
$75 \%$ cypress $-25 \%$ pine & Lignin & $8.2(3.6)$ & - \\
$100 \%$ cypress & Tannin & $1.2(0.5)$ & - \\
$100 \%$ cypress & Lignin & $0.8(0.2)$ & - \\
$100 \%$ cypress & MUF/pMDI & $0.5(0.2)$ & \\
\hline
\end{tabular}


Table 10 Percentage mean mass loss in OSB specimens, and DSI according to EN 12038 - Pleurotus ostreatus. () standard deviation Tabelle 10 Mittlerer prozentualer Masseverlust der OSB-Proben und Befallsanfälligkeitsindex (DSI) gemäß EN 12038 - Pleurotus ostreatus. () Standardabweichung

\begin{tabular}{lccc}
\hline OSB type & Resin & Average mass loss $(\%)$ & DSI (\%) \\
\hline Control & - & $23.4(6.7)$ & - \\
Cypress solid wood & - & 0.4 & - \\
$100 \%$ pine & Tannin & $31.1(3.3)$ & 98.9 \\
$100 \%$ pine & MUF/pMDI & $25.7(2.5)$ & 119.7 \\
$100 \%$ cypress & Tannin & $1.8(1.0)$ & - \\
$\mu 100 \%$ cypress & MUF/pMDI & $0.52(0.3)$ & - \\
\hline
\end{tabular}

Table 11 Analysis of variance - resin effect - decay resistance - Coniophora puteana

Tabelle 11 Varianzanalyse - Harzeinfluss - Befallsresistenz - Coniophora puteana

\begin{tabular}{lccccc}
\hline Source & DDL & Square root & Mean square & $F$ & $\operatorname{Pr}>F$ \\
\hline Model & 2 & 0.142 & 0.071 & 2.795 & 0.067 \\
Erreur & 86 & 2.190 & 0.025 & & \\
Total corrigé & 88 & 2.332 & & & \\
\hline
\end{tabular}

ture increased. The statistical analysis revealed that samples of panels with $50 \%$ cypress content exposed to $\mathrm{Co}$ niophora puteana had higher weight losses than the panels made with a mixture of species. When the mean mass loss is above $3 \%$, the degradation index also decreased when the percentage of pine increased, i.e. $22 \%$ with $25 \%$ of pine and $66 \%$ with $50 \%$ of pine. The results showed that the introduction of durable species in the composition of the panels increased the decay resistance, even if this improvement is not sufficient. These results confirmed those of several other authors (Kamdem and Sean 1994, Okoro et al. 1984, Kartal and Green 2003, Wan et al. 2007): composite material made with durable wood species are resistant to decay by wood degrading fungi. The presence of cypress may have conferred some durability to the pine panels, and extractives were absorbed by the pine particles, so this might have increased their durability. With the presence of pine, there was a greater loss of durability than with termite attack because hyphal penetration was easier in the most sensitive zones and increased the degradation. There is no significant difference between the behaviour of the OSB specimen made with cypress or pine after exposure to Coniophora puteana and Pleurotus ostreatus. Table 11 shows the results of an ANOVA to assess the effects of resin on decay resistance of wood-based composites. This analysis indicated that resins had no significant effect on OSB performance.

\section{Discussion}

The aim of this study was to assess the possibility of improving the resistance of OSB panels against termites and fungi by introducing durable species like cypress and to propose an eco friendly material by introduction of natu- ral based resin. Since there is currently no standard specifically designed to characterise the termite resistance of panels, the termite resistance of OSB panels was tested according to two European standards adapted for solid wood, i.e. EN 118 and EN 117. Because the termite resistance is based on the presence of extractives the termite resistance of the OSB panels was studied in field tests for a longer test period and the data was completed with lab results. Termite resistance was tested under tropical conditions in a field test. In a last step, the decay resistance of OSB panels against fungi was tested according to EN 12038 .

Both methods for testing the termicidal resistance of OSB panels did not allow confirming the termite resistance of the cypress-pine mixture because the validation was based on visual grading. The analysis of the results showed that termite resistance increased as the percentage of cypress increased. These two methods did not give the same degradation and mass loss levels according to the type of mixture. The level of attack was higher for EN 118 than for EN 117 because the number of termites per surface unit was higher in the first case. The mass loss obtained for EN 117 was greater because the termites were able to attack the OSB specimens and could select the most sensitive zones where the pine wood could be readily reached. The sensitivity of the different mixtures of the OSB panels is supposed to be due to the degradation of the properties of the extractives during the manufacturing process. The field test results obtained under tropical conditions complemented the study and highlighted no significant differences between panels with different cypress-pine mixtures: all OSB specimens underwent termite attack attempts and mass loss occurred of around $1 \%$. The antifeedent properties of cypress play an important role under exterior conditions because termites have a feeding choice. Savory (1969) pointed out that lab- 
oratory tests are generally more severe than exposure in service. Although the target termite species are different to those used in the laboratory tests, it could be observed that the field test results were close to those obtained for EN 117. The decay test results did not confirm the decay resistance of the cypress-pine mixture against the fungi because the mean mass loss is above $3 \%$ but the resistance increases with the percentage of cypress. Furthermore a difference between the two resins was observed: OSB specimens with lignin-based resin were more resistant against termites than those with tannin-based resin. This difference may be due to the presence of residual isocyanate groups still present in the hardened mixed lignin resin, thus contributing to its resistance (Despres et al. 2006, Wieland et al. 2006).

\section{Conclusion}

OSB specimens manufactured with cypress and pine, mixed species and natural based resins and solid wood specimens were exposed to fungal bioassays using Coniophora puteana and Pleurotus ostreatus and termite bioassays based on a no-choice test using the subterranean termite Reticulitermes santonensis and a choice test carried out under tropical conditions.

With the fungal bioassay, OSB specimens made from cypress showed more resistance against the tested fungi, the decay resistance decreased as the percentage of pine increased, and the OSB specimens made of $100 \%$ pine were non-durable. In the termite bioassays, OSB made from cypress showed more resistance against the tested termite, the resistance decreased as the percentage of pine increased, and the OSB specimens were non-durable. The degree of attack differed according to the choice of standard procedure, i.e. it was lower when the termites were not directly in contact with the test sample. The choice of resin had a significant effect with respect to termite resistance. Mass losses obtained with lignin- based resin were lower than those obtained with tannin-based resin.

The field test results revealed that in exterior conditions and when the termites had a feeding choice, all mixtures showed the same behaviour.

Since the pressure to restrict the use of wood preservatives in wood products is increasing, alternative approaches to increase the resistance of composite wood products are important. It is possible to increase the resistance of OSB products to biodegradation, especially in regions with low to moderate termite hazard using naturally durable wood species.

Acknowledgement The authors wish to thank Dr Remy Marchal and Jean Claude Buteaud, Labomap, Ecole Nationale Supérieure d'Arts et Métiers, Cluny-France.

\section{References}

AFNOR (2003) EN 12038 Durability of wood and wood-based products - Wood-based panels - Method of test for determining the resistance against wood-destroying basidiomycetesr

AFNOR (2005a) EN 117 - Wood preservatives - Determination of toxic values against Reticulitermes species (European termites) (Laboratory method)

AFNOR (2005b) EN 118 - Wood preservatives - Determination of preventive action against Reticulitermes species (European termites) (Laboratory method)

Ballerini A, Despres A, Pizzi A (2005) Non-toxic, zero-emission tannin-glyoxal adhesives for wood panels. Holz Roh- Werkst 63(6):477-478

Behr EA (1972) Decay and termite resistance of medium density fibreboards made from wood residue. For Prod J 22(12):48-51

Despres A, Pizzi A, Delmotte D (2006) 3C NMR investigation of the reaction in water of UF resins with blocked emulsified isocyanates. J Appl Poly Sci 99(2):589-596

Evans PD, Dimitriade S, Cunningham RB, Donnelly CF (2000) Medium density fibreboard manufactured from blends of white cypress pine and non-durable wood species shows increased resistance to attack by subterranean Coptotermes lacteus. Holz 54(6):585-590

Gardner DJ, Tascioglu C, Walindern ME (2003) Wood composite protection. In: Godell B, Nicholas DD, Schultz TP (eds) Wood deterioration and preservation. Advances in our changing world. Washington DC, pp 399-419

Garnier S, Pizzi A, Vorster O, Halasz L (2002) Rheology of polyflavonoid tannin-formaldehyde reactions before and after gelling - Part 2: Hardener influence and comparison of different tannins. J Appl Poly Sci 84(4):864-871

Haluk JP, Roussel C (2000) Characterization and origin of tropolones responsible for the cupressales natural durability. Potential application to wood preservation (in French). Ann For Sci 57(8):819829

Kamdem P, Sean ST (1994) The durability of phenolic-bonded particleboards made from decay resistant black locust and nondurable aspen. For Prod J 44(2):65-68

Kartal SN, Green III F (2003) Decay and termite resistance of medium density fibreboard (MDF) made from different wood species. Intern Biodeterior 51:29-35

Kirkpatrick JW, Barnes HM (2006) Biocide treatments for wood composites - A review. The International Research Group on Wood Preservation. Norway, Document No. IRG/WP 06-40323, p 21

Lei H, Pizzi A, Du G (2007) Environment-friendly, mixed tannin/lignin wood resins. J Appl Poly Sci 107(1):203-209

Mansouri NE, Pizzi A, Salvado J (2007) Lignin-based wood panel adhesives without formaldehyde. Holz Roh- Werkst 65(1):65-70

Morita Y, Matsumara E, Okabe T, Shibata M, Ohe T, Tsujibo H, Ishida N, Inamori Y (2003) Biological activity of tropolone. Biol Pharm Bul 26(10):487-1490

Muin M, Tsunoda K (2003) Termicidal performance of wood based composites treated with silafluofen using supercritical carbon dioxide. Holz 57(6):585-592

Okoro SP, Gertjejansen R, French D (1984) Influence of natural durability, laboratory weathering resin content, and ammoniacal copper arsenate treatment on the decay resistance of African hardwood particleboards. For Prod J 34(9):41-48

Savory JG (1969) Testing the fungus resistance of board materials. Materd Organism Suppl 2:49-56

Wan H, Wang XM, Yang DQ (2007) Utilizing eastern white Cedar to improve the resistance of strand boards to mould and decay fungi. For Prod J 57(3):54-59

Wieland S, Pizzi A, Hill C, Grigsby W, Pichelin T (2006). The reaction in water of UF resins with isocyanates at short cur- 
ing times: a 13C NMR investigation. J Appl Poly Sci 100 (2): 1624-1632

Yalinkilic MK, Immamura Y, Takahashi M, Kakaycioglu H, Dermici GN, Ozdemir T (1998) Biological, physical and mechanical properties of particleboards manufactured from waste leaves. Inter Bioterioration 41:75-84
Zavarin E, Smith RM, Anderson AB (1959a) Characterisation of Cupressaceae tropolone as diclohexylamine salts. J Org Chem 24:1584-1585

Zavarin E, Smith RM, Anderson AB (1959b) Paper chromatography of tropolones of Cupressaceae II. J Org Chem 24: $1318-1321$ 